\title{
Where Security Meets Justice: Prosecuting Maritime Piracy in the International Criminal Court
}

\author{
Melanie O'BRIEN* \\ Griffith University, Australia \\ melanie.obrien@griffith.edu.au
}

\begin{abstract}
The International Criminal Court (ICC) was established to prosecute crimes that "threaten the peace, security and well-being of the world". Maritime piracy has a long history as a threat to international security and was in fact the first international crime. Yet piracy was excluded from the Rome Statute. In the years since the drafting of the Rome Statute, piracy has increased dramatically to become more like the threat it was in the "Golden Age of Piracy". Criminal accountability for piracy has been minimal, due to logistical and jurisdictional difficulties. This paper offers an analysis of the potential of the ICC for prosecuting pirates: why it should be considered as a potential forum for ensuring criminal accountability for piracy, how piracy fits within the ICC's jurisdiction, and whether or not piracy should be added to the Rome Statute as a stand-alone crime or under the rubric of crimes against humanity.
\end{abstract}

The International Criminal Court (ICC) was established to prosecute crimes that "threaten the peace, security and well-being of the world". ${ }^{\mathrm{T}}$ This evidences a clear relationship between the ICC and security. Maritime piracy has a long history as a threat to international security. It was in fact the first international crime, with pirates considered hostes humani generis (enemies of humanity), and commands universal jurisdiction. However, piracy was excluded from the Rome Statute because of the fact that piracy is a crime committed for personal gain, and it is also not a crime committed by state actors. Although piracy attacks declined in the nineteenth and twentieth centuries, a new surge began in the I990s. ${ }^{2}$ In the years since the

* BA/LLB (University of Newcastle, Australia); Graduate Diploma in Legal Practice (University of Technology, Sydney, Australia); LLM in International Human Rights Law (University of Lund, Sweden); PhD (University of Nottingham, United Kingdom). Admitted Legal Practitioner (Supreme Court of NSW, Australia). Research Fellow, ARC Centre of Excellence in Policing and Security, Griffith University, Brisbane, Australia. This paper is based on a paper delivered at the 20 I 2 ANZSIL-AsianSIL Conference in Sydney, Australia. The author would like to thank Tamsin Page for a very useful discussion at that conference.

I. Rome Statute of the International Criminal Court, I7 July 1998, 21 87 U.N.T.S. 90 (entered into force I July 2002) [Rome Statute].

2. Chris BELLAMY, "Maritime Piracy: Return of the World's Second-Oldest Security Problem" (20II) I 56 The Royal United Services Institute Journal 78 at 78 . 
drafting of the Rome Statute, piracy has increased dramatically to become more like the threat it was in the "Golden Age of Piracy" (the seventeenth and eighteenth centuries). ${ }^{3}$ Piracy hot spots have changed from locations such as the Caribbean to those such as the Strait of Malacca (between Malaysia, Singapore, and Indonesia), the South China Sea, the Gulf of Guinea, and off the coast of Somalia into the Indian Ocean and the Red Sea (Gulf of Aden). ${ }^{4}$

The economic impact and human costs reveal the significant scale of the piracy problem today. Yet criminal accountability for piracy has been almost non-existent, due to logistical and jurisdictional difficulties. The ICC as a forum for prosecuting maritime pirates has been dismissed cavalierly by the UN, yet, in this case, international criminal law should be adopted as an instrument of justice. The ICC aims to prevent and punish crimes committed on a large scale, crimes that "threaten the peace, security and well-being of the world". ${ }^{5}$ Piracy is certainly being committed on a large, global scale, and impacting global security and wellbeing. It goes far beyond being merely a crime of personal gain, demonstrating the suitability of the Court as a forum for prosecuting pirates. This paper offers an analysis of the potential of the ICC for prosecuting pirates: why it should be considered as a potential forum for ensuring criminal accountability for piracy, even with non-state actors as perpetrators, whether or not piracy should be added to the Rome Statute as a stand-alone crime or under the rubric of crimes against humanity, and potential solutions for exercise of jurisdiction over crimes committed in international waters.

\section{THE PIRACY PROBLEM}

Modern piracy has a significant global impact. There were 4 IO piracy attacks in 2009, 445 in 2010, 439 in $201 \mathrm{I}$, and a drop to 297 in $2012 .{ }^{6}$ Piracy attack numbers in Asian waters (particularly around Southeast Asia, the South China Sea, India, and Bangladesh) have fluctuated in the twentieth century, with numbers rising until 2005 , then decreasing from 2006 until 20I0, after which they have increased again. Indonesian waters are a particular hot spot for piracy, with more attacks in that location than anywhere else in the world in 20I2, due to the porous borders, large number of islands, and insufficient national naval resources to patrol the waters. ${ }^{7}$

3. Ibid.; see also James KRASKA, Contemporary Maritime Piracy: International Law, Strategy, and Diplomacy at Sea (Santa Barbara, CA: Praeger, 200I) at Io-34 for a history of piracy.

4. $\quad$ Kraska, supra note 3 at $35-58$.

5. Some scholars refer to the bifurcation of the ICC into a criminal court and a "security court"; e.g. George P. FLETCHER and Jens David OHLIN, "The ICC - Two Courts in One?" (2006) 4 Journal of International Criminal Justice 428; Florian JESSBERGER and Julia GENEUSS, "The Many Faces of the International Criminal Court” (20I2) Io Journal of International Criminal Justice I08 I.

6. ICC International Maritime Bureau, "Piracy and Armed Robbery Against Ships: Report for the Period I January-3I December 20I2" (January 20I3), online: ICC 〈http://www.icc-ccs.org/piracyreporting-centre/request-piracy-report $\rangle$ at 5-6 [IMB $20 I 2$ Report $]$.

7. Ibid.; Office of the Inspector of Transport Security, Department of Infrastructure and Transport, Australia, "International Piracy and Armed Robbery at Sea Security Inquiry Report" (April 20Io), online: OITS 〈http://www.infrastructure.gov.au/transport/security/oits/piracy.aspx > at 29-3I; Mark J. VALENCIA, "Piracy and Politics in Southeast Asia" in Derek JOHNSON and Mark VALENCIA, eds., Piracy in Southeast Asia: Status, Issues, and Responses (Singapore: ISEAS Publications, 2005), 
As of I4 May 20I3, there were five vessels being held hostage and seventy-one people had been taken hostage by Somali pirates. By I4 May 20I3, there had been Ioo pirate attacks worldwide since the start of 2013 , with four of those resulting in successful hijackings. ${ }^{8}$

A report by One Earth Future's Oceans Beyond Piracy (OBP) initiative estimated Somali piracy's impact on the global economy to be US\$7 billion for 20II. ${ }^{9}$ A previous report by OBP estimated the global cost of piracy for 2010 to be in the range of US\$7 to US\$ I 2 billion. ${ }^{\text {Io }}$ These costs are caused by a number of factors. In the shipping sector, there has been an increase in:

- Insurance costs;

- Private security on ships travelling through piracy hot spots;

- Amount of money demanded for ransoms; ${ }^{\text {I }}$

- The cost of fuel caused by the need to travel at faster speeds to avoid pirate attacks and/or the need to reroute into a longer route to avoid attacks;

- The purchase of “ship hardening” security equipment to protect against pirate attacks; and

- Salaries for ship labourers travelling through high-risk areas. ${ }^{\text {I2 }}$

Piracy also puts an increased strain on naval resources. US\$2 billion is spent each year on naval operations off the coast of Somalia. The OBP report on the Economic Cost of Piracy 2010 found the naval cost to come from two main sources:

(I) The cost of each contributing naval vessel. We calculate these costs by using approximations of the cost of deploying a ship per steaming day, and multiply this number by the number of vessels deployed each year (currently around 43); (2) The administrative and staffing budgets of the "big three" naval operations: Operation Atalanta, Operation Ocean Shield, and Combined Task Force I 5 I. ${ }^{\text {I3 }}$

In addition to the economic costs, the distribution of states' naval resources across the globe may cause a reduction in the military capabilities of those states, causing insecurity and a lack of defensive competence over a state's own territory.

I03-2I at I05; Sam BATEMAN, "Confronting Maritime Crime in Southeast Asian Waters: Reexamining 'Piracy' in the Twenty-first Century” in Bruce A. ELLEMAN et al., eds., Piracy and Maritime Crime: Historical and Modern Case Studies (Newport, RI: Naval War College, 20IO), $\mathrm{I} 37^{-}-53$ at $\mathrm{I} 48-9$.

8. ICC International Maritime Bureau, "Piracy \& Armed Robbery News \& Figures" (May 20I3), online: ICC 〈http://www.icc-ccs.org/piracy-reporting-centre/piracynewsafigures $\rangle$.

9. Oceans Beyond Piracy, "The Economic Cost of Somali Piracy 20I I" (February 20I 2), online: Oceans Beyond Piracy 〈http://oceansbeyondpiracy.org/cost-of-piracy/economic $\rangle$.

Io. Oceans Beyond Piracy, “The Economic Cost of Maritime Piracy” (December 20I0), online: Oceans Beyond Piracy 〈http://oceansbeyondpiracy.org/cost-of-piracy/economic 〉.

II. See e.g. SC Res. 2020 (20II); Report of the Monitoring Group on Somalia and Eritrea Pursuant to Security Council Resolution 2002 (20II), UN Doc. S/20I2/544 Annex 4I (I3 July 20I2), at I95 [UN Monitoring Group Report 2012].

I2. Ibid.

I3. Ibid.; see supra note го. 
The economic effects of piracy are felt not just by corporations but have a trickledown effect on the everyday consumer by increasing costs of products and services such as energy, due to the increased cost of transporting these goods and services. Pirate attacks have also had an impact on the provision of goods including humanitarian aid, with World Food Programme (WFP) transportation ships also being attacked. ${ }^{\mathrm{I}}$ This has increased UN costs, with additional funding having to be provided for the airlifting of food that would otherwise be transported by sea. ${ }^{15}$ With respect to Somalia, between eighty and ninety-five percent of assistance to Somalia by the WFP is transport by sea, but this aid to Somalia has been reduced by half as a consequence of piracy in the region. ${ }^{\mathrm{I}}{ }^{6}$

The human cost is also high. Most of the attacks involve the use of weapons, which causes risk to the ship, cargo, and the environment, but most importantly risk of injury and death to seafarers. The IMB reports that, from 2007 to 2012 , fortyeight people were killed as a result of piracy attacks, and 243 injured. ${ }^{17}$ While the number of deaths may appear relatively low, the number of people taken hostage in the same period is staggering: 4,792. ${ }^{18}$ In addition, the OBP reports on violence against hostages after the actual hijacking and kidnapping, including conduct such as beatings; deprivation of food and water; being shot at with water cannons; being locked in the ship's freezer; being tied up in the hot sun; being kept in solitary confinement; being forced to parade naked; mock executions; and denial of medical care. $^{\text {I9 }}$ Some seafarers have been forced to collaborate with the pirates, while others have been used as human shields. ${ }^{20}$

Piracy has become a form of organized crime, which involves "a global network of ... financial backers and touches tens of thousands of beneficiaries at the local, state and region level-what some analyses call the "pirate value chain'". ${ }^{21}$ The spread of crime includes offences such as money laundering and corruption. Those involved are not just the pirates themselves, but also government officials. ${ }^{22}$ This is in keeping with the history of piracy, which has, at different periods of time, included raiding and privateering, where pirates were funded by the state (or a more local level official) to conduct raids as a means of resourcing the state (particularly in times of

\footnotetext{
I4. Report of the Secretary-General on the Situation in Somalia, UN Doc. S/2007/38 I (25 June 2007), at para. $5 \mathrm{I}$.

I5. Ibid., para. 58 .

I6. This figure was given as $80 \%$ in 2007: Report of the Secretary-General on the Situation in Somalia, UN Doc. S/2007/658 (7 November 2007), at para. 22; this figure was given as 95\% in 2009: Report of the Secretary-General Pursuant to Security Council Resolution I 846 (2008), UN Doc. S/2009/I 46 (2009), at 9, para. 35 .

I7. IMB $20 I 2$ Report, supra note 6 at II; ICC International Maritime Bureau, "Piracy and Armed Robbery Against Ships: Report for the Period I January-3I December 20I I" (London: January 2OI2).

I8. IMB 2012 Report, supra note 6 at II; ICC International Maritime Bureau, supra note I7.

I9. Oceans Beyond Piracy, "The Human Cost of Somali Piracy" (6 June 20II), online: Oceans Beyond Piracy 〈http://oneearthfuture.org/images/imagefiles/HCOP_Paper_FINAL_Ipdf〉at I6- I9.

20. Ibid., at I8-19.

2I. Jatin DUA and Ken MENKHAUS, "The Context of Contemporary Piracy: The Case of Somalia" (20I2) Io Journal of International Criminal Justice 749 at $75 \mathrm{I}$.

22. Ibid. at 756-7.
} 
war), particularly in the European and Asian contexts. ${ }^{23}$ Piracy thrives in situations of state instability, in turn increasing such instability. ${ }^{24}$ Some Asian pirates are small-time robbers, but many are part of large criminal networks that also engage in other transnational organized crimes such as people smuggling, drug smuggling, prostitution, and arms trafficking. ${ }^{25}$ With the increase in power of terrorist organizations such as al-Shabaab, there are also concerns about the links between piracy and terrorism (for example, pirates paying "territorial access" fees to al-Shabaab groups who control a particular coastal territory). ${ }^{26}$ There is also a distinct overlap between maritime piracy and maritime terrorism in the Southeast Asian waters. ${ }^{27}$

\section{PIRACY PROSECUTIONS}

The obstructions to the prosecution of maritime pirates are a source of frustration to legal and security scholars and practitioners. Jurisdiction, logistics, and imprisonment solutions are the main barriers to prosecution. By the start of 20I2, $\mathrm{I}, 063$ total prosecutions had been held worldwide. ${ }^{28}$ Out of these, 6I 2 have been convicted worldwide. In Somalia, there have been 334 convictions, with 60 of those convicted subsequently released. Examples of states who have held significant numbers of piracy prosecutions are Kenya (I43 held, 50 convicted), Yemen (I 23 convicted, 6 acquitted), and India (II9 held); although prosecutions have taken place in much smaller numbers in many countries across the globe including Belgium, Japan, the Netherlands, Madagascar, Malaysia, the Republic of Korea, China, and the US. ${ }^{29}$

23. Adam J. YOUNG, "Roots of Contemporary Maritime Piracy in Southeast Asia" in Johnson and Valencia, supra note 7, I-33; Robert J. ANTONY, "Piracy on the South China Coast through Modern Times" in Ellemen et al., supra note 7, 35-50.

24. Adam J. YOUNG, Contemporary Maritime Piracy in Southeast Asia: History, Causes and Remedies (Singapore: ISEAS Publishing, 2007) at 57-II3; Martin N. MURPHY, "Piracy and the Exploitation of Sanctuary" in Jeffrey H. NORWITZ, ed., Pirates, Terrorists, and Warlords (New York: Skyhorse Publishing, 2009), I66-76 at I68; see also generally Elleman et al., supra note 7.

25. See generally Parts One and Two of Elleman et al., supra note 7.

26. C. SINGH and A.S. BEDI, "WWar on Piracy': The Conflation of Somali Piracy with Terrorism in Discourse, Tactic and Law" (2012) 543 ISS Working Paper Series / General Series I; see also UN Monitoring Group Report 20I2, supra note II, for discussion throughout about al-Shabaab and pirates.

27. Graham Gerard ONG, "Ships Can Be Dangerous, Too: Coupling Piracy and Terrorism in Southeast Asia's Maritime Security Framework" in Johnson and Valencia, supra note $7,45-76$; Mark J. VALENCIA, "Piracy and Terrorism in Southeast Asia: Similarities, Differences and Their Implications" in Johnson and Valencia, supra note 7, 77-102; Bateman, supra note 7 at I $37-53$.

28. Report of the Secretary-General on Specialized Anti-piracy Courts in Somalia and other States in the Region, UN Doc. S/2012/50 (20 January 2012), at 5 .

29. Ibid. See e.g. Antony, supra note 23 at 35-6; Jamie DAVIS, "Somali Man Convicted of Piracy for Role in German, US Hijackings" Jurist (28 April 20I 2), online: Jurist < http://jurist.org/paperchase/ 2OI 2/04/somali-man-convicted-of-piracy-for-role-in-german-and-us-hijackings.php $\rangle$; Dan TAGLIOLI, "Somali Pirate Negotiator Sentenced to I2 Life Sentences" Jurist (I4 August 20I 2), online: Jurist 〈http://jurist.org/paperchase/20 I 2/o8/somali-pirate-negotiator-sentenced-to-I2-life-sentences.php 〉; Maggie GARDNER, "Piracy Prosecutions in National Courts" (20I2) ro Journal of International Criminal Justice 797 . 
Prosecutions have many difficulties for individual states, due to costs and logistics, ${ }^{30}$ even for those who are taking steps to prosecute, such as India. India is in the process of updating its piracy legislation in order to ensure effective prosecution of pirates. ${ }^{31}$ However, it has encountered obstacles in prosecutions such as "finding qualified Somali-speaking interpreters, procuring deposition evidence from victims, and dealing with the sheer volume of cases on backlog". ${ }^{22}$ Other countries, such as China, also do not actually have legislation proscribing piracy, and instead use general criminal provisions, ${ }^{33}$ and under the UN Convention on the Law of the Sea (UNCLOS), they are not required to do so. ${ }^{34}$ These types of problem are likely to be encountered by many states when undertaking piracy prosecutions; and they are complications that the ICC could more easily overcome (e.g. through permanently appointed interpreters).

Prosecution of piracy is permitted under universal jurisdiction, but this is only possible when crimes are not committed in territorial waters. ${ }^{35}$ While Security Council Resolutions (the most recent being SCRes 2077 of 201 2) permit states to enter Somali territorial waters to pursue and capture pirates, the enactment of universal jurisdiction is particularly problematic for crimes committed in the Malacca Strait, which is all territorial waters (Singapore, Malaysia, and Indonesia), and the South China Sea, over which territorial disputes are ongoing. ${ }^{36}$

This lack of prosecutions means that piracy is an attractive option for disenfranchised locals from littoral states such as Somalia or Indonesia, affected by poverty, conflict, and instability. Piracy offers high incentives (monetary rewards), but low risks (extremely low likelihood of punishment), which amounts to there being no real deterrence to commit the crimes. ${ }^{37}$ Pirates are motivated

30. Elizabeth ANDERSON et al., "Suppressing Maritime Piracy: Exploring the Options in International Law”, American Society of International Law, Workshop Report, I6- I7 October 2009 at 8. Another disincentive is an inability or unwillingness to imprison convicted pirates or to deal with asylum claims subsequent to release; Anderson et al., at 8.

3I. Roger L. PHILLIPS, "India: A Case Study" Piracy-Law.com (24 September 20II), online: PiracyLaw.com 〈http://piracy-law.com/20II/og/24/india-a-case-study/〉; "New Law to be Enacted to Prosecute Sea Pirates: Govt to SC" The Hindu (I2 April 20I3), online: The Hindu <http:// www.thehindu.com/news/international/new-law-to-be-enacted-to-prosecute-sea-pirates-govt-to-sc/ article46ro286ece $>$.

32. Roger L. PHILLIPS, "Language, Capacity Issues Plague Indian Prosecutions of Somali Pirates” PiracyLaw.com (I February 20I3), online: Piracy-Law.com 〈http://piracy-law.com/2013/o2/oI/languagecapacity-issues-plague-indian-prosecutions-of-somali-pirates $/\rangle$.

33. ZOU Keyuan, "Enforcing the Law of Piracy in the South China Sea" (2000) 3I Journal of Maritime Law and Commerce 107 at II4-I5.

34. J. Ashley ROACH, "General Problematic Issues on Exercise of Jurisdiction over Modern Instance of Piracy" in Clive R. SYMMONS, ed., Selected Contemporary Issues in the Law of the Sea (Leiden: Martinus Nijhoff Publishers, 20II), II9-37 at I3I-2.

35. Anderson et al., supra note 30.

36. The separate disputes are between China and the Philippines and Japan; see e.g. Bonnie GLASER, "Trouble in the South China Sea" Foreign Policy.com (I7 September 20I2), online: Foreign Policy. 6com 〈http://www.foreignpolicy.com/articles/20I2/o9/I 7/trouble_in_the_south_china_sea 〉; Dapo AKANDE, "Philippines Initiates Arbitration Against China over South China Seas Dispute” Blog of European Journal of International Law (22 January 2013), online: EJIL: Talk! 〈http:// www.ejiltalk.org/philippines-initiates-arbitration-against-china-over-south-china-seas-dispute/ $\rangle$.

37. Adam CRAWFORD, "Crime Prevention and Community Safety" in Mike MAGUIRE et al., eds., The Oxford Handbook of Criminology (Oxford: Oxford University Press, 2007), 867-909 at 877 . 
offenders: ${ }^{3}$ motivated by poverty, state weakness, societal violence, and political, physical, and economic insecurity, to seek income by whatever means possible. ${ }^{39}$ There are large numbers of suitable, accessible targets, $4^{\circ}$ with thousands of ships passing through the zones favoured by pirates, whether that is the Gulf of Aden or the Straits of Malacca. Finally, there is an absence of capable guardians: ${ }^{4 \mathrm{r}}$ the open ocean is a vast expanse of water that belongs to no state, and is extremely difficult to police, resulting in very few pirates being captured and prosecuted.

\section{THE ICC AS A FORUM FOR PROSECUTION OF PIRACY}

Piracy was the first recognized "international crime", ${ }^{42}$ with pirates being regarded as hostes humani generis, and subject to universal jurisdiction. ${ }^{43}$ Despite this fact, and despite piracy being initially proposed as a crime to be included within the jurisdiction of the permanent international criminal court, as a consequence of the negotiations for the establishment of a permanent international criminal court, piracy was excluded from the Rome Statute. The reasoning behind this includes the fact that piracy is a crime for personal gain, committed by non-state actors. ${ }^{44}$ This was a reasoning that failed to recognize that other crimes under the Rome Statute are/can also be committed for personal gain and/or by non-state actors (for example, a non-state rebel or a civilian can commit the war crime of looting for personal gain). In addition, the present involvement of government officials (such as in Somalia or Southeast Asia) ${ }^{45}$ in the "piracy chain" demonstrates that state actors can also participate in the crime, even if they are not the principal actors out on the water hijacking ships. In addition, negotiations focused on "core crimes", rather than crimes already existing under treaties (such as piracy). More proposals were made for the inclusion of the crimes of terrorism and drug trafficking than for piracy, yet these were also rejected in the trend to exclude treaty crimes. ${ }^{46}$

38. Stephen E. BROWN et al., Criminology: Explaining Crime and Its Context, 7 th edn. (New Providence, NJ: LexisNexis, 2010) at $172-3$.

39. Young, supra note 24; Dua and Menkhaus, supra note $2 \mathrm{I}$.

40. Brown et al., supra note 38 at I73; Anthony E. BOTTOMS, "Place, Space, Crime, and Disorder" in Maguire et al., supra note $37,528-74$ at 540.

4I. Brown et al., supra note 38 at $\mathrm{I} 73$; Bottoms, supra note 37 at 540 .

42. Although note this is only the case since the late 1800 , as prior to that pirates actually worked for states; Antonio CASSESE, International Criminal Law, 2nd edn. (Oxford: Oxford University Press, 2008) at I2; Lucas BENTO, "Toward an International Law of Piracy Sui Generis: How the Dual Nature of Maritime Piracy Law Enables Piracy to Flourish" (20II) 29 Berkeley Journal of International Law 399 at 402.

43. The Case of the S.S. "Lotus" (France v. Turkey), Dissenting Opinion of Judge Moore, PCIJ, Ser. A., no. Io (1927) at 70 [Lotus case].

44. Cassese, supra note 42 at 54 .

45. Dua and Menkhaus, supra note 2I; generally Elleman et al., supra note 7.

46. Christopher Keith HALL, "The First Two Sessions of the UN Preparatory Committee on the Establishment of an International Criminal Court" (I997) 9I American Journal of International Law I77 at I79; Roy S. LEE, ed., The International Criminal Court: The Making of the Rome Statute Issues, Negotiations, Results (The Hague: Kluwer Law International, 1999) at 85-7; Neil BOISTER, "International Tribunals for Transnational Crimes: Towards a Transnational Criminal Court?" (2OI2) 23 Criminal Law Forum 295 at 296-9. 
With the re-expansion of piracy in recent years, practitioners and scholars have examined the possible options for prosecuting pirates who operate outside the territory of states. A range of options have been proposed both by scholars and by UN bodies. These include the enhancement of regional capacity to try pirates (e.g. Horn of Africa states for Somali pirates); the creation of a new Somali court within the territory of a third state; the creation of a special chamber within the courts of a regionally located state (Kenya has been a targeted state ${ }^{47}$ ); the adoption of a regional tribunal; and the establishment of an international tribunal (including by the Security Council's Chapter VII mandate). ${ }^{48}$ The ICC has rarely been considered as an option, and when it has, it has been "considered not to be feasible" without real consideration and without any explanation of how that conclusion was reached. ${ }^{49}$

In her article "Bringing Pirates to Justice",50 Yvonne Dutton offers the sole scholarly discussion to date on the potential of the ICC as a forum for prosecuting pirates. Dutton refers to the reluctance of negotiators in Rome to include treatybased crimes, including piracy, due to concerns such as overburdening the Court and the belief that a national forum would be more appropriate for treaty-based crimes. ${ }^{5}$ However, the growth of piracy and lack of prosecutions thereof demonstrate that national solutions have proven to be inadequate with regards to piracy crimes. This includes the judgments themselves, with Gardner criticizing that: "The first wave of domestic piracy prosecutions suggests, however, that domestic courts have yet to achieve the necessary consistency and expertise in resolving key questions of international law in these cases." ${ }_{52}$ What has also emerged from the reports and academic publications on piracy prosecutorial options is an emphasis on solutions for the Somali pirate crisis, but not a consideration of options for prosecuting pirates who operate in other areas of the world or have other nationalities. ${ }^{53}$ Thus, the ICC presents a prosecutorial option that covers piracy crimes committed in any location. ${ }^{54}$

One logistical area in which the ICC may struggle if it came to piracy prosecutions is resources. Dutton incorrectly states that the ICC "is well-equipped with significant resources and personnel at its disposal to handle that burden". ${ }^{55}$ In fact, the ICC's

47. See Yvonne M. DUTTON, "Bringing Pirates to Justice: A Case for Including Piracy within the Jurisdiction of the International Criminal Court" (2010) I I Chicago Journal of International Law I 97 at $220-3$.

48. Report of the Secretary-General on Specialized Anti-piracy Courts in Somalia and other States in the Region, UN Doc. S/2012/50 (2012); Douglas GUILFOYLE, "Prosecuting Somali Pirates: A Critical Evaluation of the Options" (2012) Io Journal of International Criminal Justice 767; Kraska, supra note 3 at 168-82; Bento, supra note 42 at 44I-7; Report of the Secretary-General on Possible Options to Further the Aim of Prosecuting and Imprisoning Persons Responsible for Acts of Piracy and Armed Robbery at Sea Off the Coast of Somalia, UN Doc. S/2010/394 (2010) [SG's 20I0 Report on Somali Piracy Prosecutions].

49. SG's 2010 Report on Somali Piracy Prosecutions, supra note 48 at 37.

50. Dutton, supra note 47 .

5I. Ibid., at 238.

52. Gardner, supra note 29 at 797.

53. See all references at supra note 48 .

54. This raises the issue of enactment of the ICC's jurisdiction, which is addressed infra.

55. Dutton, supra note 47 at 239. 
budget is limited, the Court is understaffed, and its current staff overworked. ${ }^{56}$ The number of staff at the Court has remained approximately consistent since 2009, as has the budget, resulting in high pressures on staff and long working hours. ${ }^{57}$ This is despite the increase in the number of investigations and cases since the start of 2009, including the addition of the situations of Kenya, Côte d'Ivore, Mali, and Libya; the issuance of multiple summonses to appear; and the commencement of a number of trial proceedings. ${ }^{8}$ However, as a solution to this, the funding that would otherwise be put into the establishment of a new court (in whatever guise-national chambers or international tribunal) can instead be provided to the ICC. This is a more efficient use of resources, rather than spending inordinate amounts of money on the establishment of a new chambers or tribunal, when one already exists that can undertake the same work. ${ }^{59}$

In addition, the practicalities of amending the Rome Statute are manageable. Under Article I2 I of the Rome Statute, an amendment can be submitted at any time by any State Party to the Rome Statute. Obviously the proposal of an amendment would not be without its difficulties, but is achievable. Previous amendments demonstrate the potential for polar experiences of proposals. For example, the amendment of the crime of aggression had extremely lengthy, drawn-out negotiations over several years, and resulted in an amendment that may not come into force until after $2017 .^{60} \mathrm{In}$ contrast, the amendments of three crimes added to war crimes were the result of much shorter negotiations, and came into force immediately. ${ }^{6 \mathrm{r}}$ Piracy would likely fall somewhere in between these two types of amendment in terms of negotiations and entry into force. In terms of negotiations, while piracy is nowhere near as controversial a crime as

56. The 2013 budget of the Court is just over EUR I I 8 million. This covers only 766 staff, including a mere 2 I 8 staff in the Office of the Prosecutor and 48 in the Judiciary (this numbers include both professional and general support staff); Assembly of States Parties to the Rome Statute of the International Criminal Court, Eleventh Session, The Hague I4-22 November 20I2, Official Records Volume II, ICC-ASP/II/2O, at $\mathrm{I}_{72-3}$. This budget has to encompass a vast array of costs for investigations, trials, field offices, supplies, contractual services, training, travel, furniture and equipment, the permanent premises, and more. Assembly of States Parties to the Rome Statute of the International Criminal Court, Eleventh Session, The Hague I4-22 November 2012, Official Records Volume II, ICC-ASP/I I/20 at I70-3. There has been a push from some of the highest-paying Member States (France, Germany, Italy, Japan, and the UK) to adopt a "zero-growth" position where the budget is not increased, "even if its activities increase or other costs rise"; Jonathan O'DONOHUE, "Financing the International Criminal Court" (2013) I 3 International Criminal Law Review 269 at 280. This is despite the protests of other Member States, the President, and the Registrar that imposition of such a budget would profoundly damage "the Court's ability to deliver fair and expeditious justice”. O'Donohue, at 28I, citing President of the ICC Judge Sang-Hyun Song, I2 December 20II. This statement is also based on the author's experience working at the Court; and personal statements and experiences of staff at the Court in recent years revealed to the author during on-site research.

57. ASP Official Records (in either Volume II or Part III) over the past years provide the following statistics: numbers were lowest in the early years of the Court: 2004-375 staff; 2005-489 staff. From 2006, numbers rose to a level maintained for three years: 2006-624 staff; 2007-647 staff; 2008-679 staff. Staff numbers rose by about Ioo in 2009 and have remained consistent since then: $2009-762$ staff; 20I0-79I staff; 20II-775 staff; 20I2-769 staff. All Official Records are available online: 〈http:// www.icc-cpi.int/en_menus/asp/sessions/official\% 2orecords/Pages/official\% 2orecords.aspx $\rangle$.

58. See generally International Criminal Court, "Situations and Cases", online: ICC $\langle$ http://www.icc-cpi. int/en_menus/icc/situations \% 20and \% 2ocases/Pages/situations $\%$ 2oand $\%$ 2ocases.aspx $\rangle$.

59. Dutton, supra note 47 at 232.

6o. Art. 8 bis of the Rome Statute, insertion through RC/Res.6, I I June 20 Io.

6I. Sub-arts. 8(2)(e)(xiii), (xiv), (xv). 
aggression (which was the reason for the length of negotiations on the latter), ${ }^{62}$ there is no single agreed-upon definition (see below), and the process for all the State Parties to reach an agreement may take time. However, with the agreement of a definition and consequential adoption of an amendment, given the current piracy problem, it is likely that the State Parties would agree to an immediate entry into force, rather than a delayed one.

As an alternative, Dutton also makes an interesting proposal of making an amendment through the means of an optional protocol, through which a separate chamber for piracy prosecutions could be created. Dutton suggests that this separate chamber would then be able to sit either in The Hague, or in a location closer to or in the region where the piracy crimes were committed. ${ }^{63}$ Resource-wise, this suggestion has its benefits and downsides: the benefits are reduced costs for transporting witnesses over long distances, and greater ease in obtaining witness evidence and other tangible evidence; the negatives are the greater cost of moving all of the chamber personnel to another location for a temporary period, and the potential for witness interference due to proximity to the crime groups. However, Dutton's suggestion is certainly one with possibilities.

It must also be remembered that the ICC is always to be considered a court of last resort. That is, national courts have primacy, and only when they are unable or unwilling to undertake investigations and prosecution will the ICC have jurisdiction. This means that the ICC would be part of a global justice scheme for piracy prosecutions, and not the only answer to the prosecution dilemma. National courts would indeed continue to have jurisdiction over piracy, and no doubt be encouraged to do so by the ICC, one of whose roles is to promote comprehensive national legislation and enactment thereof with regards to ICC crimes. What adopting an amendment to the Rome Statute on the crime of piracy will do is to help states with the current debate over the definition of piracy, which continues due to the differing definitions ${ }^{64}$ contained in the UNCLOS ${ }^{65}$ and the UN Convention for the Suppression of Unlawful Acts against the Safety of Maritime Navigation (CSUA). ${ }^{66}$ These differences undoubtedly contribute to the inconsistency in domestic judgments highlighted by Gardner. ${ }^{67}$

Therefore, there is a need for discussion over the potentiality of the ICC to prosecute those accused of maritime piracy. This paper will look at the issue of the

62. Roger S. CLARK, "Negotiating Provisions Defining the Crime of Aggression, Its Elements and the Conditions for ICC Exercise of Jurisdiction over It" (2009) 20 European Journal of International Law I I03; Marina MANCINI, "A Brand New Definition for the Crime of Aggression: The Kampala Outcome" (2OI2) 8I Nordic Journal of International Law 227; and the (20I2) Io Journal of International Criminal Justice, Ioth Anniversary Special Issue-Aggression: After Kampala, eds. Claus KRESS and Philippa WEBB.

63. Dutton, supra note 47 at 233.

64. Rytis SATKAUSKAS, "Piracy at Sea and the Limits of International Law" (20II) I Aegean Review of the Law of the Sea 217 .

65. UN Convention on the Law of the Sea, Io December I982, I833 U.N.T.S. 3, 21 I.L.M. I26I (entered into force I6 November 1994) [UNCLOS].

66. UN Convention for the Suppression of Unlawful Acts Against the Safety of Maritime Navigation, I678 U.N.T.S. 22 I, 27 I.L.M. 668 (entered into force I March I992) [CSUA].

67. Gardner, supra note 29 at $809-\mathrm{I} 8$. 
substantive law side of this discussion. First, the option to include piracy as its own, new crime through an amendment to the Rome Statute will be considered. Then the analysis will turn to the possibility of using crimes currently under the jurisdiction of the Rome Statute. Finally, issues raised concerning the triggering of ICC jurisdiction will be assessed. There are, of course, many more elements that could be discussed, such as issues of evidentiary collection (chain of evidence), logistics of mutual legal assistance (e.g. with regards to the transfer of prisoners, including through the territory of non-state parties), and arresting authorities, but these issues are outside the scope of this paper.

\section{A. Piracy as a New ICC Crime}

As previously mentioned, piracy was the original international crime, with the recognition of pirates as hostes humani generis. The ICC was established to ensure accountability for perpetrators of "the most serious crimes of concern to the international community as a whole" ${ }^{68}$ The ICC has jurisdiction over "grave crimes that threaten the peace, security and well-being of the world". ${ }^{69}$ Maritime piracy is decisively recognized as a major and significant threat to the peace, security, and wellbeing of the world. ${ }^{\circ}$ It is a major issue discussed regularly by the Security Council, which repeatedly passes resolutions with the aim of combating piracy, and receives reports from the Secretary-General on various aspects of combating piracy and ensuring accountability for piracy perpetrators. ${ }^{71}$ The Deputy Secretary-General has called piracy a "global concern" that "affects the freedom of shipping and the safety of shipping lanes that carry about 90 per cent of the world's trade". ${ }^{72}$ The Security Council has called piracy a threat to "international navigation, the safety of commercial maritime routes, and the security and economic development of States in the regions concerned, as well as to the safety and welfare of seafarers and other persons, including through their being taken as hostages", and condemned "in the strongest terms hostage taking and the use of violence against hostages". ${ }^{73}$ Shipping is a global industry, and therefore the impact of these crimes is felt globally. Ships are sailed under the flags of all countries around the globe; seafarers come from any and all countries; passengers are also of all nationalities; goods being shipped start from and are destined to be delivered to any number of states (usually multiple throughout

\footnotetext{
68. Rome Statute, supra note I, Preamble.

69. Ibid.

70. E.g. Natalie KLEIN, Maritime Security and the Law of the Sea (Oxford: Oxford University Press, 2OII) at II 8-27; Rachel BAIRD, "Transnational Security Issues in the Asian Maritime Environment: Responding to Maritime Piracy" (20I2) 66 Australian Journal of International Affairs 50I-I3; Bellamy, supra note 2.

7I. Crucial reports include those at supra note 48. Resolutions include I846 (2008); I85 I (2008); 2020 (20II); and 2077 (20I2). However, again the emphasis on the Somali pirates must be noted. While it is true that piracy originating from Somalia is having the greatest impact on international peace and security, attention should also be paid to combating piracy in other regions where it persists.

72. "UN Deputy Secretary-General Flags Need for 'Multi-Dimensional' Approach to Combating Piracy", UN News Centre (I9 November 20I2), online: UN News Centre 〈http://www.un.org/apps/news/ story.asp? NewsID $=43538 \#$. UgIjyWTk64Q $>$.

73. Statement by the President of the Security Council, UN Doc. S/PRST/201 2/24 (2012).
} 
a single voyage which stops at different ports). Piracy has become a conglomerate operation, with "wide networks of investors, negotiators and others stretching across countries and continents ... a trans-regional economy with deep connections to other forms of privatized enterprise on both land and sea". ${ }^{74}$ Therefore it is clear that international peace and security is jeopardized by maritime piracy.

The international impact demonstrates the gravity of the crime of piracy. There are several other factors that demonstrate the gravity of a crime before the ICC, including "the scale, nature, manner of commission, impact of crimes committed on victims and the existence of aggravating circumstances (i.e. qualitative dimension)". ${ }^{75}$ With regard to the scale of the crimes, piracy is committed across huge expanses of the globe, and has resulted in thousands of victims. The geographical spread also demonstrates the widespread nature ${ }^{76}$ of the crimes. The impact of the crimes on victims has been significant, resulting in physical and psychological injuries, including post-traumatic stress disorder. Many incidences of piracy contain aggravating circumstances, namely the use of violence and the taking of hostages. Therefore, an overall assessment of these factors shows that piracy is a crime that fits within the ambit of the ICC as a grave crime of most serious concern to the international community.

The definition of a new crime of piracy will need to be produced from a consensus development from the definitions found in the UNCLOS and the CSUA. Article IOI of the UNCLOS defines piracy as consisting of any of the following acts:

(a) any illegal acts of violence or detention, or any act of depredation, committed for private ends by the crew or the passengers of a private ship or a private aircraft, and directed:

(i) on the high seas, against another ship or aircraft, or against persons or property on board such ship or aircraft;

(ii) against a ship, aircraft, persons or property in a place outside the jurisdiction of any State;

(b) any act of voluntary participation in the operation of a ship or of an aircraft with knowledge of facts making it a pirate ship or aircraft;

(c) any act of inciting or of intentionally facilitating an act described in subparagraph (a) or (b).

The CSUA does not use the word "piracy" but, in Article 3(I), states that any person commits an offence if that person unlawfully and intentionally:

a. seizes or exercises control over a ship by force or threat thereof or any other form of intimidation; or

74. Dua and Menkhaus, supra note 2I at 750, 76I.

75. Decision Pursuant to Art. I5 of the Rome Statute on the Authorization of an Investigation into the Situation in the Republic of Kenya, Situation in the Republic of Kenya (ICC-or/o9-19), Pre-Trial Chamber II, 3I March 2010 at para. I88 [Kenya Investigation Decision].

76. Ibid., at paras. $\mathrm{I} 9 \mathrm{I}-6$. 
b. performs an act of violence against a person on board a ship if that act is likely to endanger the safe navigation of that ship; or

c. destroys a ship or causes damage to a ship or to its cargo which is likely to endanger the safe navigation of that ship; or

d. places or causes to be placed on a ship, by any means whatsoever, a device or substance which is likely to destroy that ship, or cause damage to that ship or its cargo which endangers or is likely to endanger the safe navigation of that ship; or

e. destroys or seriously damages maritime navigational facilities or seriously interferes with their operation, if any such act is likely to endanger the safe navigation of a ship; or

f. communicates information which he knows to be false, thereby endangering the safe navigation of a ship; or

g. injures or kills any person, in connection with the commission or the attempted commission of any of the offences set forth in subparagraphs (a) to (f).

Under the principle of legality, for the purposes of a provision to be applicable for a criminal judicial system, a clearly defined definition of the crime must be drafted. For example, the UNCLOS definition of "any illegal acts of violence or detention" is far too broad, as is the CSUA's "act of violence", and does not provide the court or the defendant with enough information as to what conduct is prohibited. A provision like Article $3(\mathrm{I})(\mathrm{g})$ of the CSUA would be more appropriate, where a person commits a crime if they injure or kill any person while committing or attempting to commit an act of piracy. In addition, specific crimes such as hostage-taking and torture should be included. However the definition should not be so limited as to exclude any acts of violence perpetrated during the commission. To do this, the definition could take from other crimes in the Rome Statute, such as "other inhumane acts of a similar character intentionally causing great suffering, or serious injury to body or to mental or physical health". ${ }^{77}$

A comprehensive definition would include aspects of both conventions' definitions, although it may not include them all. For example, the UNCLOS definition of piracy focuses on violence, detention, and robbery, whereas the emphasis of the CSUA crimes is on damage or destruction of a ship or its cargo and endangerment of the safe navigation of a ship. The CSUA crimes are quite broad, and on their own, may be too broad for ICC jurisdiction, in that intentional damage of a ship could occur in non-piratical circumstances that do not amount to a crime serious enough to be an international crime. Thus, any reference to ship damage or destruction would have to be specifically within the context of the participation of the main elements of piracy, namely committed during the acts of "violence, detention or depredation". 
The CSUA also includes the modes of liability of attempt, abetting, and threatening another person to commit these offences..$^{78}$ Modes of liability with regard to piracy will be crucial, in order to capture the variety of levels of offenders involved in the piratical system. For example, a crime may be included that covers the funding of piracy operations, for those who provide money and/or resources, but do not participate in the ship hijackings directly. Alternatively, such conduct may be covered under a mode of liability such as aiding and abetting, or contributing to the crime. The mode of liability of contributing under the Rome Statute is to be committed "with the aim of furthering the criminal activity or criminal purpose of the group". ${ }^{79}$ In addition, ordering, soliciting, and inducing the commission of a crime ${ }^{8 \circ}$ could be used in the case where pirates force seafarers to participate in their crimes, for example by piloting the ship. Given the hierarchical and even military structure of pirate groups, command and superior responsibility would also be a vital mode of liability for prosecutors to use. ${ }^{8 \mathrm{r}}$ Another important mode of liability would be attempt, as many ship hijackings are attempted but unsuccessful (although due to the increased use of weapons by pirates, may still result in injuries to people and damage to ships).

\section{B. Piracy as a Crime Against Humanity}

Failing the introduction of a new, specific crime of piracy, it would be possible for the ICC to prosecute crimes of piracy under any of the current Rome Statute crimes. This paper will focus on prosecuting piracy crimes under Article 7, crimes against humanity. This is due to the fact that it is evident that piracy is not a genocidal crime, with an intent to destroy a particular group in whole or in part. Nor can pirates be considered as engaging in armed conflict or as combatants. To qualify as an armed conflict, there must be "resort to armed force between States or protracted armed violence between governmental authorities and organized groups or between such groups with a state". ${ }^{82}$ Any fighting taking place during a piracy attack is sporadic and not protracted. Guilfoyle has offered a concise analysis of why the laws of war do not apply to pirates, and thus this paper will not go further into that topic. ${ }^{8}{ }^{8}$ Hence, this section will consider whether piracy crimes would fall under the rubric of crimes against humanity.

\footnotetext{
78. CSUA, supra note 66, art. 3(2).

79. Rome Statute, supra note I, art. $25(3)(\mathrm{d})$.

8o. Ibid., art. $25(3)$ (b).

8I. Dua and Menkhaus discuss IMB findings of the main Somali pirate groups, with commanders and a military structure; supra note $2 \mathrm{I}$ at $76 \mathrm{I}$.

82. Prosecutor v. Tadic, Decision on the Defence Motion for Interlocutory Appeal on Jurisdiction, Case No. IT-94-I, 2 October I995, para. 70.

83. Douglas GUILFOYLE, "The Laws of War and the Fight Against Somali Piracy: Combatants or Criminals?" (20IO) I I Melbourne Journal of International Law I4I. This author will make one comment on Guilfoyle's paper. Guilfoyle notes that the chain of command in "pirate gangs" is not sufficient to engage the accountability of a military or even civilian commander / superior-subordinate relationship, as it is "far from established that pirates are organised in any manner analogous to military discipline" (at I46). It has been established that many pirate groups have a distinct hierarchical structure, including commanders and in some cases a military structure; see Dua and Mekhaus, supra note $2 \mathrm{I}$ at $76 \mathrm{I}$ (referring to IMB findings). Therefore, as noted in the main text above, command and superior responsibility would be a highly relevant mode of liability for prosecution.
} 


\section{Widespread or systematic attack against a civilian population}

The first chapeau element of crimes against humanity is that the crime is committed as part of a widespread or systematic attack directed against a civilian population. The words "widespread" and "systematic" are disjunctive, meaning that the crime must be committed as part of either a widespread attack or a systematic attack directed against a civilian population. ${ }^{{ }^{4}}$

"Widespread" is not a reference to geographical location, but to the number of victims. ${ }^{{ }_{5}}$ The ad hoc tribunals have given the term an expansive definition covering "the large-scale nature of the attack and the number of targeted persons". ${ }^{86}$ Even though "widespread" does not necessarily refer to geographical spread, in the case of piracy, the geographical distribution of the crimes being committed is relevant. The reach of pirates is expanding. For example, Somali pirate attacks alone now cover an area of over 7.3 million square kilometres. To put this in perspective, the country of Australia is just over 7.6 million square kilometres in size. In addition, the attacks are large scale in nature in that they are continuing over many years and targeting hundreds to thousands of ships. This is certainly more "widespread" in temporal terms than, for example, the Côte d'Ivoire Gbagbo case presently before the ICC, which covers crimes committed over only a four-month period; and in geographical terms than crimes committed within only part of the territory of that country, the whole of which measures just over 322,000 square kilometres. ${ }^{87}$ The number of targeted persons is also extremely high, as the figures cited earlier in this paper demonstrate, with hundreds of people injured and almost 5,000 people taken hostage. Although in some ICC cases the number of victims is far greater, these kinds of figure are still large

84. Kenya Investigation Decision, supra note 75 at 94; Prosecutor v. Sesay, Kallon and Gbao (RUF Case), Trial Judgment, Case No. SCSL-04-I 5-T, 2 March 2009 at 78; Antonio CASSESE, "Crimes Against Humanity" in Antonio CASSESE et al., eds., The Rome Statute of the International Criminal Court (Oxford: Oxford University Press, 2002), 353-78 at 366; Antonio CASSESE, International Criminal Law, 2nd edn. (Oxford: Oxford University Press, 2008) at 99; Rodney DIXON and Christopher K. HALL, "Crimes Against Humanity-Chapeau" in Otto TRIFFTERER, ed., Commentary on the Rome Statute of the International Criminal Court, 2nd edn. (Muenchen/Oxford/Baden-Baden: C.H. Beck, Hart, Nomos, 2008), at I76-8; Theodor MERON, "Crimes Under the Jurisdiction of the International Criminal Court” in Herman VON HEBEL et al., eds., Reflections on the International Criminal Court (The Hague: TMC Asser Press, I999), 47-55 at 50; Herman VON HEBEL and Darryl ROBINSON, "Crimes within the Jurisdiction of the Court" in Roy S. LEE, ed., The International Criminal Court: The Making of the Rome Statute (The Hague: Kluwer Law International, I999), $79-\mathrm{I} 26$ at $94^{-5}$.

85. Dixon and Hall, supra note 84 at 178.

86. Prosecutor v. Kordic, Appeal Judgment, Case No. IT-95/I4/2-A, I7 December 2004, 94. See also Prosecutor v. Blaskic, Appeal Judgment, Case No. IT-95-I4-A, 29 July 2004, IоI; Prosecutor $v$. Kunarac et al. (Foca), Appeal Judgment, Case No. IT-96-23 \& IT-96-23/I-A, I 2 June 2002, 94. The ICTR has used almost identical language: "the scale of the attacks and the multiplicity of the victims"; Prosecutor v. Muyunyi, Trial Judgment, Case No. ICTR-oo-55AT, I2 September 2006, 5I2; Prosecutor v. Muhimana, Trial Judgment, Case No. ICTR-95-IB-T, 28 April 2005, 527; Prosecutor v. Semanza, Trial Judgment, Case No. ICTR-97-20-T, I5 May 2003, 329; Prosecutor v. Musema, Appeal Judgment, Case No. ICTR-96-I3-A, 27 January 2000, 203-4. See also Katanga and Chui, Decision on the Confirmation of Charges, ICC-oI/O4-01/07, 30 September 2008 at 394; Kenya Investigation Decision, supra note 75 at 95 .

87. From I6 December 2010 until I2 April 20II; Situation in the Republic of Cote D'Ivoire, Warrant Of Arrest For Laurent Koudou Gbagbo, Case No. ICC-02/II, 23 November 20II, at 7 and para. 7 . 
enough to match other ICC situations and cases, which also have thousands of victims. ${ }^{88}$

A systematic attack is one with an "organised nature of the acts of violence and ... improbability of their random occurrence", showing "patterns of crimes, in the sense of the non-accidental repetition of similar criminal conduct on a regular basis" ${ }^{89}$ Other courts and tribunals have held that the term "reflects the organised nature of the attack, excludes random violence, and does not require a policy or plan".90 However, under Article 7(2)(a) of the Rome Statute, the attack must be "pursuant to or in furtherance of a State or organizational policy to commit such an attack", the policy of which is understood to require either active promotion or encouragement of such an attack. ${ }^{9 \mathrm{r}}$ The Court has interpreted this to mean that while the policy does not have to be explicitly defined, the attack "must be thoroughly organised and follow a regular pattern", and "also be conducted in furtherance of a common policy involving public or private resources". ${ }^{92}$ The general pattern of the attacks will demonstrate the systematic nature of the crimes. ${ }^{93}$

Pirate attacks may have started years ago as random events, but the organized nature of attacks has developed significantly, and attacks are no longer spontaneous. A UN Report found:

Somalia's two main pirate groups, the Puntland Piracy Network (PPN) and the Hobyo-Harardheere Piracy Network (HHPN), both remain active, well-organized and continue to operate from their usual anchorages, chiefly Harardheere (HHPN), Garacad (PPN), and a pirate camp some I7 nautical miles north of Bandar Beyla (PPN). From these and other, smaller bases, the pirates range across an immense area comprising the southern Red Sea, Gulf of Aden, Indian Ocean (east and south of Somalia down to the north of Mozambique), Arabian Sea and Gulf of Oman. Decreased success rates have been matched by increasingly protracted ransom negotiations, longer periods of captivity for hijacked crews and escalating ransom payments. ${ }^{94}$

88. See this author's previous comments on the "magic number" required for a situation or case to be considered of sufficient gravity to be admissible before the ICC, and why numbers should not be the only measurement of gravity; Melanie O'BRIEN, "The Impact of the Iraq Communication of the Prosecutor of the International Criminal Court on War Crimes Admissibility and the Interests of Victims” (2007) Symposium Edition, University College Dublin Law Review Io9; Melanie O’BRIEN, "Prosecutorial Discretion as an Obstacle to Prosecution of United Nations Peacekeepers by the International Criminal Court: The Big Fish/Small Fish Debate and the Gravity Threshold” (2012) IO Journal of International Criminal Justice 525 .

89. Kordic, Appeal Judgment, supra note 86 at 94; Blaskic, Appeal Judgment, supra note 86 at IoI; Foca, Appeal Judgment, supra note 86 at 96; RUF Case, supra note 84 at 78 . See also Katanga and Chui, Confirmation of Charges, supra note 86 at 394, 397; Kenya Investigation Decision, supra note 75 at 96.

90. Muyunyi, Trial Judgement, supra note 86 at 5I2; RUF case, supra note 84 at 84 . Allison Marston DANNER, "Constructing a Hierarchy of Crimes in International Criminal Law Sentencing” (200I) 87 Virginia Law Review 4I 5 at 474.

9I. Elements of Crimes, UN Doc. PCNICC/2000/I/Add.2 (2000), Article 7 Crimes Against Humanity, Introduction (3) [Elements of Crimes].

92. Katanga and Chui, Confirmation of Charges, supra note 86 at 396; Kenya Investigation Decision, supra note 75 at 84 .

93. Gbagbo Arrest Warrant, supra note 87 at para. 7 .

94. UN Monitoring Group Report 20I2, supra note II at I95. 
Attacks are sometimes planned over a period of weeks, with pirate attack teams assessing the security situation and determining attack strategies in advance. ${ }^{95}$ Pirates are increasingly organized and funded (including through private resources). For example, groups now use "mother ships", large ships that are anchored in one location as the "pirate base" from which smaller, faster boats are launched from which attacks are conducted. This has contributed to the increasing reach of pirates, who are now able to cover large swathes of the ocean for potential ships to target. As a consequence of better operations with more successful thefts, pirates now have access to faster boats. Victims, shipping companies, and negotiators have remarked on what has become business-like conduct in the negotiation of ransoms. Pirate groups have also adopted informal "codes" between them, to ensure no group encroaches on the "territory" of another group (a sort of "honour among thieves"). On land and at the coast, there are protection rackets, linked to territorial control. That is, pirates charge local fishermen or other shipping vessels for "protection" from attacks when travelling through their "zone". In addition, as previously mentioned, many groups now have an organized and often military structure, including powerful commanders such as warlords. ${ }^{96}$ All of these factors clearly demonstrate an organizational policy to commit attacks, adding up to a systematic framework of piracy crimes. The organized nature and the pattern should be considered in the light of all pirate attacks, and not just those committed by each pirate group, although there is certainly sufficient organization within each group. The ICC has also ruled that one way of determining organization is to examine "whether a group has the capability to perform acts which infringe on basic human values". ${ }^{97}$ Finally, the crimes of piracy committed by Somali pirates can be linked to the Somali government's failure to take action, and/or to government involvement in the crimes. The collapse of the state in Somalia has led to weak governance, where corruption is rife and government officials accept payoffs from pirates..$^{98}$ This in turn leads to unwillingness to actually eliminate piracy.

It is only the attack that must be widespread or systematic. ${ }^{99}$ The criminal behaviour of the accused may be a single act or limited number of acts occurring in the context of the attack against a civilian population, and cannot be isolated, limited, or random. ${ }^{\text {10 }}$ While, in the context of categorizing armed conflict, the pirate attacks can be considered sporadic, this is different from the context of crimes against humanity. The crimes may be isolated from each other geographically, but they are not isolated in that there are multiple, ongoing attacks from each pirate

\footnotetext{
95. Ibid., at 198 .

96. The excellent research by Dua and Menkhaus, including with Somali pirates, details all of these factors; supra note $2 \mathrm{I}$.

97. Kenya Investigation Decision, supra note 75.

98. Dua and Menkhaus, supra note $2 \mathrm{I}$ at $756-6 \mathrm{I}$.

99. Kordic, Appeal Judgment, supra note 86 at 94; Blaskic, Appeal Judgment, supra note 86 at IоI; Foca, Appeal Judgment, supra note 86 at 96.

Iоo. Kordic, Appeal Judgment, supra note 86 at 94; Blaskic, Appeal Judgment, supra note 86 at IoI; Foca, Appeal Judgment, supra note 86 at 96; Tadic, Trial Judgment, Case No. IT-94-I-T, 7 May I997, 649; Prosecutor v. Jean-Pierra Bemba Gombo, Decision Pursuant to Article 6I(7)(a) and (b) of the Rome Statute on the Charges of the Prosecutor Against Jean-Pierre Bemba Gombo (Bemba charges decision), ICC-or/o5-or/o8, P.T.Ch.II, I 5 June 2009, 77 and 8I; Kenya Investigation Decision, supra note 75 at $8 \mathrm{I}$ and 85 .
} 
group. Thus, each attack is in the context of a broader attack on the civilian population. The attacks are not random, but planned, sometimes even for weeks.

The targeted civilian population must also be specified. In the RUF case, the Special Court for Sierra Leone (SCSL) examined whether the killing of peacekeeping personnel fell within the scope of crimes against humanity. Trial Chamber I held that "the attacks against UNAMSIL personnel were geographically and temporally removed from the crimes against civilians" found proven under other charges in the case. ${ }^{\text {or }}$ It was found that the peacekeeping personnel were not killed in connection with these other crimes or further crimes against civilians. The categorization of the peacekeeping personnel was actually distinguished from the civilians of Sierra Leone-they were civilian peacekeeping personnel, but not the civilian population that was the target of the widespread or systematic attack. ${ }^{102}$ Thus, despite the fact that the peacekeeping personnel were held to be civilians, the Trial Chamber held that the attacks were "distinct from and did not form part of the widespread or systematic attack on the civilian population of Sierra Leone". ${ }^{\text {гз }}$ To this issue, while it is true that each ship attacked is geographically removed from the other attacked ships, these are not separate groups of civilians. The civilian population being attacked are those located on all the ships, be they seafarers working on the ships, or passengers on board. Only military vessels may be considered not to constitute part of the civilian population targeted by the pirates, as they are clearly able to defend themselves. The status of private security may also be at issue, given they are armed and have an organized structure. However, they are not military and therefore should still be considered civilians. The targeted civilians can be of any nationality or ethnicity, or they may possess other distinguishing features, which allows for the attack to include multinational and multi-ethnic shipping crews. ${ }^{\text {IO4 }}$

\section{Individual crimes}

There are a number of individual crimes under Article 7 of the Rome Statute that could be used to prosecute piracy crimes. However, these will all be limited to crimes against the person, and will not cover any crimes relating to the damage, destruction, or theft of the ship-which demonstrates why there is a need for a separate, new provision proscribing piracy.

The most obvious crime to use would be "imprisonment or other severe deprivation of physical liberty". ${ }^{\text {ros }}$ This would be applicable in the case of hostage-taking, whether those hostages were kept on the boat, on a pirate boat, or on land. Being held hostage is clearly a severe deprivation of liberty, which requires an arbitrary deprivation of liberty of movement without due process of law. ${ }^{106}$ The imprisonment or deprivation of liberty

\footnotetext{
IоI. RUF case, supra note 84 at I952. UNAMSIL was the United Nations Mission in Sierra Leone, from I999 until 2006.

I02. Ibid., at $1953-4$.

I03. Ibid., at I953.

104. Situation in the Republic of Cote D'Ivoire, Decision Pursuant to Article I 5 of the Rome Statute on the Authorisation of an Investigation into the Situation in the Republic of Côte d'Ivoire, Pre-Trial Chamber III, Case No. ICC-02/I I, 3 October 20II, at para. 32.

105. Rome Statute, supra note I, art. 7(I)(e).

I06. Elements of Crimes, supra note 75; Prosecutor v. Kordić \& Čerkez, Trial Judgement, IT-95-I4/2-T, 26 February 2001, at para. 302.
} 
can include a situation where a person is physically unable to move, but also where a person can continue to move (such as in a concentration camp).

Second, the Prosecutor could bring charges of torture under Article 7(I)(f). Under the Rome Statute, torture is defined as "the intentional infliction of severe pain or suffering, whether physical or mental, upon a person in the custody or under the control of the accused; except that torture shall not include pain or suffering arising only from, inherent in or incidental to, lawful sanctions". ${ }^{107}$ Once a person is taken hostage, they are in the custody and under the control of the pirate(s). Earlier in this paper there was a list of examples of violence committed against hostages by pirates: beatings; deprivation of food and water; being shot at with water cannons; being locked in the ship's freezer; being tied up in the hot sun; being kept in solitary confinement; being forced to parade naked; mock executions; and denial of medical care. Some of these crimes have already been held to amount to torture: withholding food or water; exposure to extreme temperatures; beating; being held incommunicado in solitary confinement; being restrained; and mock executions. ${ }^{\text {ros }}$ The specific conduct that constitutes torture is broad and depends on the circumstances, provided it results in severe physical or mental pain or suffering.

If the conduct of the pirates was found not to reach the threshold of torture, then charges could be brought under the "catch all" crime, Article $7(\mathrm{I})(\mathrm{k})$, for "other inhumane acts of a similar character intentionally causing great suffering, or serious injury to body or to mental or physical health". For example, in the International Criminal Tribunal for the Former Yugoslavia's Foca case, various forms of forced nudity such as parading or dancing were determined to constitute the war crime of outrages upon personal dignity. ${ }^{109}$ While "outrages upon personal dignity" does not exist as a crime against humanity, "inhumane acts" are a similar concept which includes crimes such as forced marriage, and therefore being forced to parade naked would also fall within its remit.

Finally, the crime of murder ${ }^{\text {1о }}$ could be applied to any person killed during the commission of hijackings or after being taken hostage. The actus reus of this crime is that the perpetrator must have caused the death of another person.

\section{Jurisdictional concerns}

The ICC does not have automatic jurisdiction over a person who commits a crime of the Rome Statute. There are restrictions on the Court's ability to exercise jurisdiction.

\footnotetext{
107. Rome Statute, supra note I, art. 7(2)(e).

108. See for example: Report of the Special Rapporteur on the Question of Torture and Other Cruel, Inhuman or Degrading Treatment or Punishment, UN Doc. A/56/I56, 3 July 200I, paras. 8-I4; ICCPR General Comment 7 (Sixteenth session, I982): Article 7: Torture or Cruel, Inhuman or Degrading Treatment or Punishment, UN Doc. A/37/40 (1982) 94 at para. 2; Muteba v. Zaire, UN Doc. I24/I982 (24 July I984); Gonzalez v. Uruguay, UN Doc. A/37/40 (29 March I992); Arzuaga v. Uruguay, UN Doc. I47/I983 (I November I985); Herrera Rubio v. Colombia, UN Doc. I6I/I983 $(2$ November 1987); Acosta v. Uruguay, UN Doc. I62/1983 (25 October 1988); A.R. v. The Netherlands (203/2002), CAT, A/59/44 (I 4 November 2003) 247 (CAT/C/3I/D/203/2002).

I09. Prosecutor v. Kunarac et al. (Foca), Trial Judgement, IT-96-23-T \& IT-96-23/I-T, 22 February 200I, at paras. 766--74.

I Iо. Rome Statute, supra note I, art. 7(I)(a).
} 
The ICC can only investigate and prosecute a case if a state is unwilling or unable to do so; ${ }^{\text {II }}$ and if the crime was committed either by a national of a State Party or in the territory of a State Party. ${ }^{\text {I2 }}$ As discussed above, states are often unwilling and/or unable to prosecute pirates. For example, states in Africa and Asia may be willing but not able to do so due to a lack of resources to conduct trials, as evidenced above by the example of India and its difficulties in conducting piracy prosecutions. Therefore, this provision would not likely be at issue, given that the idea behind suggesting the ICC as a forum for prosecuting pirates is because nation-states are not making much headway in doing so.

It is the latter precondition to the exercise of jurisdiction that is of concern. If a crime is committed by, for example, a Somali pirate, or an Indonesian pirate, in international waters, how can the ICC obtain jurisdiction over him? Neither Somalia nor Indonesia is a party to the Rome Statute. The Rome Statute only applies within the territory of State Parties, not in international waters. There are three solutions. The first solution is to consider the flag nationality of the ship. If the attacked ship is flagged with the nationality of a State Party to the Rome Statute, then it could be claimed that State Party has jurisdiction, as vessels are subject to the authority of the state whose flag they fly. ${ }^{\text {I3 }}$ Therefore, crimes committed on that vessel are subject to the jurisdiction of the flag nation-state. Inevitably, this solution creates a jurisdictional lacuna for ships that belong to non-state parties.

The second solution is for State Parties to apply the principle of passive personality jurisdiction. ${ }^{\mathrm{II}} \mathrm{A}$ State Party to the Rome Statute could claim its jurisdiction over a person for committing a crime against one of its own nationals, and then through this, refer the case to the ICC (under Article I4, which allows for a state referral of a situation). Of course, this option will only work for State Parties, unless a non-state party is willing to refer a perpetrator. ${ }^{115}$

The third and final solution is for the Security Council to refer "the piracy situation" to the ICC. Under Article I3(b), the Court may exercise jurisdiction over crimes committed in a situation referred to the Prosecutor by the Security Council acting under Chapter VII of the UN Charter. This enables the Security Council to refer crimes to the Court that were not necessarily committed by State Party nationals or within the territory of a State Party to the Rome Statute. The Security Council has already done so for the situations in Darfur, Sudan, and Libya. ${ }^{116}$

\footnotetext{
III. Ibid., art. I7.

II2. Ibid., art. I2.

II3. Lotus case, supra note 43 at 25; UNCLOS, supra note 65, arts. 91, 92, 94.

I 4. Ian BROWNLIE, Principles of Public International Law, 7 th edn. (Oxford: Oxford University Press, 2008) at 304 .

I I. This is unlikely, given that there is generally a significant opposition to the Court by non-State Parties, including the US (although the US does seem to be softening its stance somewhat). See e.g. David P. FORSYTHE, "International Criminal Justice and the United States: Law, Culture, Power" in Ramesh THAKUR and Peter MALCONTENT, eds., From Sovereign Impunity to International Accountability: The Search for Justice in a World of States (Tokyo/New York/Paris: United Nations University Press, 2004) 6I.

II6. Resolutions I 593 (2005) and I970 (20II). Although this power is not without its challenges; see e.g. Dapo AKANDE, "The Legal Nature of Security Council Referrals to the ICC and its Impact on Al Bashir's Immunities" (2009) 7 Journal of International Criminal Justice 333.
} 
The Security Council has also already availed itself, as previously mentioned, of the piracy issue, promulgating resolutions and presidential statements aimed at combating piracy and seeking a solution for prosecution of piracy crimes. Thus it would be within the power and the interests of the Security Council to refer "the piracy situation" to the ICC. However, there would be a need for a certain amount of specificity with regard to the geographic location of the crimes, as a broad allocation of jurisdiction to the ICC over piracy regardless of the location of commission would not be in keeping with the provisions or the spirit of the Rome Statute. In addition, this would create concerns over sovereignty. One alternative is for the location of the crimes encompassed in a referral to be specific to one ocean or maritime passage, e.g. the Indian Ocean, or the referral could encompass all international waters. However, a referral would be problematic or even impossible in relation to piracy hot spots in territorial waters, such as the Malacca Strait and the South China Sea-particularly given the fact that the only littoral state in these areas that is a party to the Rome Statute is the Philippines. That leaves the territorial waters of states such as China, Indonesia, Malaysia, and Singapore outside the jurisdiction of the ICC. While situations in other non-State Parties have been referred by the Security Council to the ICC (Sudan and Libya), these states are all extremely protective of their sovereignty, and it is highly unlikely that a piracy situation in their territorial waters would ever be referred by the Security Council to the ICC. This is particularly due to the fact that China has a right of veto in the Security Council, and will exercise its veto in order to protect its own territorial sovereignty and those of regional allies.

\section{CONCLUSION}

Without a doubt, maritime piracy is a threat to international peace and security. Piracy is not just about the theft of a ship, but all the crimes that go along with that robbery. Such crimes include hostage-taking, infliction of grave injuries, torture, and even killing. The impact of piracy is felt most by its direct victims: those on the ships that are hijacked. These victims experience physical and mental suffering, the consequences of which can last for years. However, the growth and spread of piracy is creating an effect that stretches beyond oceans and beyond borders. Consumers are paying more for goods due to rising prices caused by the increasing costs of shipping. Humanitarian aid recipients are at risk of starvation and disease because of lack of supplies due to disruption to WFP shipping routes and ship hijacking. Piracy is becoming a more intricate and organized criminal enterprise engaging a business-like approach and involving pirates, financial backers, racketeering, government corruption, and possibly terrorist group links. Therefore, it is crucial that steps are taken to prevent and punish piracy crimes. A discussion of the issues behind piracy (and its growth) and prevention solutions was out of the scope of this paper, but the roots of piracy in state collapse, conflict, and instability demonstrate that the piracy problem is an international peace and security issue at both ends of the spectrum.

Prosecutions have been few and far between compared to the number of attacks and victims over the past decade. After a steady rise in attack numbers, the number of attacks dropped in 20I2. However, the attacks themselves have become more 
violent and more costly, with increasing ransom demands. Therefore it is vital that pirates are punished for the crimes they commit. Along with other prevention methods (for example, dealing with economic and political instability in pirates' home states), punishment needs to take on the role of deterrence. Currently, pirates are not deterred from piracy due to the low risk of being detained and prosecuted, and the high rewards they receive as a result of their actions.

Many judicial options have been presented, but one forum has been almost ignored as a potential solution for taking on some piracy prosecutions. That forum is the International Criminal Court. While promoting the jurisdiction of the ICC, this does not mean to say that nation-states should not pursue prosecutions. The ICC should be used in the way it was meant to, under its complementarity principle, only where states are unwilling or unable to prosecute these serious international crimes. In adopting a provision proscribing piracy, the ICC could contribute towards the development of a universally accepted definition of piracy (through the statutory provision and also its jurisprudence), and encourage states to adopt comprehensive legislative provisions prohibiting piracy. The adoption of an amendment to the Rome Statute of the crime of piracy would be the best option for the ICC. However, if that is not achievable, there are currently some crimes under the jurisdiction of the ICC under which the Prosecutor could lay charges against pirates. These are crimes against the humanity of imprisonment or other deprivation of liberty, torture, inhumane treatment, and murder. Depending on specific crimes, others may also be applicable (e.g. rape).

It is far from efficient to put funding and other resources into the creation of a new court, whether that is a special national chamber or an international tribunal, when a court already exists that can take on the role of prosecuting piracy. If the resources were put into the ICC instead, prosecutions could start far sooner than if the process of establishing a new court had to be gone through.

The comprehensive response required from the international community sought by the Security Council ${ }^{117}$ should include the ICC, a court developed and established by the international community for the very purpose of ensuring accountability for serious and grave international crimes.

I 7. “Security Council Stresses Need for Comprehensive Global Response to Tackle Piracy” UN News Centre (2I November 20I2), online: UN News Centre 〈http://www.un.org/apps/news/ story.asp? NewsID $=43569 \# . U g Y z 9 m T k 58 \mathrm{~A}>$. 